\title{
The 1872 Mining Law: Historical Origins of the Discovery Rule
}

Under the General Mining Law of $1872,{ }^{1}$ a prospector may purchase title in fee simple to unappropriated federal land for a nominal charge if he discovers a "valuable deposit" of minerals. ${ }^{2}$ Since the General Mining Law does not define a "valuable deposit," courts employ various tests to determine when a person makes such a discovery. The two principal discovery tests, based in part on conflicting interpretations of the Law's purposes, are the prudent man rule and the marketability rule.

Under the prudent man rule, a claim is regarded as valuable if a reasonably prudent person would expend additional money working the claim. The marketability rule considers a claim valuable only if the minerals on the claim can be currently marketed at a profit. The prudent man rule is more easily satisfied and promotes broad private use of mineral resources. The marketability rule more effectively safeguards other federal interests, such as the preservation of public land for beneficial nonmineral uses.

Part I of this comment describes the development of the different tests used to determine when a claim includes a valuable mineral deposit. It also suggests that the prudent man rule derives from a particular understanding of the legislative purposes of the General Mining Law. Advocates of the rule often believe that the Law was designed to promote the interests of individual miners. Consequently, they favor the more easily satisfied prudent man rule, which would guarantee that public lands remain open to almost any individual mineral exploitation.

Part II begins by noting that the prudent man rule is at odds with the statutory language. It then focuses on historical evidence to demonstrate that the General Mining Law was not a homestead act tailored for indigent prospectors, as advocates of the prudent man rule erroneously assume. Rather the Law was created to promote the operations of early mining corporations. Finally, it argues that the prudent man rule conflicts with less anachronistic federal (1982)).

2 Act of May 10, 1872, ch. 152, 17 Stat. 91 (codified as amended at 30 U.S.C. $\S \S 21-54$

30 U.S.C. $\S \S 22,29,37$ (1982). 
policies that govern the disposition of federal lands in other areas. Contemporary notions of environmental quality and multiple purpose land use counsel in favor of a more restrictive rule of discovery.

This comment concludes that the plain meaning of the Law, its purposes, and other modern concerns all indicate that the marketability rule is the preferable discovery standard.

\section{Competing Discovery Standards}

The General Mining Law of 1872 governs the exploitation of minerals on federal lands. ${ }^{3}$ It declares "[a]ll valuable mineral deposits in lands belonging to the United States . . . shall be free and open to exploration, and purchase, and the lands in which they are found to occupation and purchase." The Law applies principally to hard-rock or metallic minerals such as gold, silver, lead, tin, copper, nickel, molybdenum, uranium, and others. ${ }^{5}$ It does not apply to minerals such as common varieties of sand, gravel, and stone, ${ }^{6}$ nor to organic compounds such as coal, ${ }^{7}$ oil, and gas. ${ }^{8}$

3 The General Mining Law of 1872 codified two earlier laws: the Lode Mining Act of July 26, 1866, ch. 262,14 Stat. 251 (codified as amended at 30 U.S.C. $\$ \S 43,46,51,53$ (1982)), and the Placer Mining Act of July 9, 1870, ch. 235, 16 Stat. 217 (codified as amended at 30 U.S.C. $\$ \S 35-36,38,47,52$ (1982)). The Placer Mining Act gave locators of placer deposits the same rights to locate ("stake") a claim and purchase title to the land (patent the claim) as the Lode Mining Act gave to locators of mineral lodes. See Placer Mining Act of July 9, 1870, ch. 235, § 12, 16 Stat. 217 (codified as amended at 30 U.S.C. $\$ 35$ (1982)).

Lodes are ore deposits in place-formations of gold, silver, or other minerals running many feet or miles into the earth. A placer is a superficial deposit, usually of auriferous (goldbearing) gravels, found in the beds of ancient rivers or valleys. Placer deposits are usually former lodes that have been broken down, transported, and redeposited in alluvial sediment by exposure to flowing water. Placers often can be mined by one person; lodes usually require considerably more capital for tunnels and shafts. See United States v. Iron Silver Mining Co., 128 U.S. 673, 683 (1888); 1 E.O. MARTZ, American LAw of MinING § 1.16 (1983).

130 U.S.C. $\$ 22$ (1982). The Public Land Law Review Commission estimated in 1970 that total federal land holdings were 755.4 million acres, or about one-third of the nation's 2.3 billion acres. Public Land Law Review Comm'n, One Third of the Nation's Land 2022,27 (1970). The federal government in 1982 owned $729,820,861.4$ acres, or $32.1 \%$ of the nation's land. U.S. Dep'T of Interior, Public Land Statistics 10 (1984).

s See 30 U.S.C. \$§ 23, 35 (1982).

- See The Common Varieties Act of 1955, ch. 375, § 3, 69 Stat. 368 (codified as amended at 30 U.S.C. $\$ 611$ (1982)).

7 See The Coal Act of 1864, ch. 205, 13 Stat. 343; Coal Act of 1873, ch. 279, 17 Stat. 607, superseded by The Mineral Lands Leasing Act of 1920, ch. 85, 41 Stat. 437.

- See The Mineral Lands Leasing Act of 1920, ch. 85, 41 Stat. 437 (codified as amended at 30 U.S.C. $\S \S 181-287$ (1982)) (enacting a leasing system for coal, gas, oil shale, phosphate, sulphur, potassium, sodium, asphalt, bitumen, and tar sands). The Mining Law 
Under the Law, anyone may enter federal land to search for and develop minerals without obtaining permission or paying a fee. ${ }^{9} \mathrm{~A}$ person who discovers a valuable deposit of minerals can secure exclusive rights to remove them simply by locating ("staking") a claim..$^{10}$ The "locator" then holds the exclusive right to possession and enjoyment of the mineral deposit as long as the boundaries of the location are properly traced and the locator invests $\$ 100$ worth of labor or improvements each year. ${ }^{11}$

A locator who wishes to obtain full title in fee simple to both the minerals and the surface may obtain a "patent for any land claimed and located for valuable deposits."12 The locator who patents a claim avoids the annual labor and improvements conditions imposed on unpatented claims. Pursuant to Congress's refusal to permit wholesale privatization of federal lands, and instead to

also does not cover land used by the Defense Department, 30 U.S.C. $\$ 601$ (1982), nor does it apply to land in national parks or monuments, 16 U.S.C. $\$ \S 1901-1912$ (1982). Mining is allowed, however, in national forests. See Friends of the Earth, Inc. v. Butz, 406 F. Supp. 742, 744 (D. Mont. 1975), remanded as moot, 576 F.2d 1377 (9th Cir. 1978). Federal lands in several midwestern states are expressly reserved for agricultural activities and excluded from the Mining Law. See, e.g., 30 U.S.C. $\$ 49$ (1982) (excluding Missouri and Kansas). The Federal Land Policy and Management Act of 1976, § 204, 43 U.S.C. $\$ 1714$ (1982), authorizes the Interior Secretary to withdraw certain federal lands from settlement, location, or entry.

After taking account of all these exclusions, approximately $60 \%$ of federal land is open to development. See Kinkead, James Watt's Self-Made Storm, Fortune, Nov. 30, 1981, at 138, 146; see also U.S. Congress Orfice of Technology Assessment, Management of Fued and Nonfuel Minerals in Federal Land 337 (1979) (determining that $33.9 \%$ of federal lands are formally closed and $6.1 \%$ are so highly restricted as to greatly discourage development).

- See 30 U.S.C. § 22 (1982); see also Public Land Law Review Comm'N, supra note 4, at 124.

${ }^{10}$ See 30 U.S.C. § 26 (1982) (locator's right of possession and enjoyment); id. § 28 (method and conditions for locating a claim). A lode claim can be up to 1,500 feet long and 600 feet wide, id. $\S 23$, while a placer claim is limited to 20 acres, $i d$. $\S 35$. Locators may also get use of or patent title to 5 acres for a mill site. Id. $\S 42$. The exact method of locating a claim depends on the specific laws of the mining district. Id. $\S 28$.

Originally, staking a claim literally meant marking the land with boundary stakes and filing the location in the state or territorial land office. Id. $\$ 29$. Beginning in 1976, locators were also required to report their claims to a federal agency, the Bureau of Land Management. 43 U.S.C. $\$ 1744$ (1982). This heritage of unregulated location of mining claims has made modern land management difficult. For example, from 1968 to 1974 the Department of the Interior spent 100 man-years and $\$ 1.9$ million to clear title to oil shale lands in three states. Only 6,000 of 56,000 mining claims were cleared. U.S. Generac Accounting OfFice, Modernization of 1872 Mining Law Needed to Encourage Domestic Mineral Production, Protect the Environment, and Improve Public Land Management at ii-iii (1974).

${ }^{11} 30$ U.S.C. $\S 28$ (1982).

12 Id. $\$ 29$. The fee paid to the government for obtaining a patent is nominal: $\$ 5.00$ per acre for lode patents, $i d$., and $\$ 2.50$ per acre for placer patents, $i d$. $\S 37$. No restrictions exist on the number of patents an individual or corporation may hold. Id. $\S 29$. 
yield title only when a person discovers a "valuable mineral deposit,"13 courts must closely examine whether the person has in fact located such a deposit.

\section{A. Judicial Tests for "Valuable Mineral Deposits"}

Early courts developed two distinct tests to determine when a person discovers a "valuable mineral deposit": the prudent man rule and the marketability rule. ${ }^{14}$ Each rule had its adherents and remained in use until 1968 when, in United States v. Coleman, ${ }^{15}$ the Supreme Court determined that the two tests were essentially identical. This mistaken conclusion continues to cause confusion in the lower courts over the appropriate standard.

1. The Prudent Man Rule. The prudent man rule originated in Castle v. Womble, ${ }^{18}$ an 1894 administrative decision upholding a location for a lode of gold-bearing quartz. The Interior Secretary determined that the statutory requirements for the discovery of a valuable deposit are met "where minerals have been found and the evidence is of such a character that a person of ordinary prudence would be justified in the further expenditure of his labor and means, with a reasonable prospect of success, in developing a valuable mine."17 Though the Secretary's statement is the most quoted formulation of the prudent man rule, it is often restated as requiring that the miner has a "reasonable expectation of profit."18 The prudent man rule rests on the future expectations of the locator; the present profitabililty of the mine is irrelevant. ${ }^{19}$

1s See Cole v. Ralph, 252 U.S. 286, 307 (1920) ("Certainly it was not intended that a right to a patent could be founded upon nothing more than holding and prospecting, for that would subject non-mineral land to acquisition as a mining claim."); see also 2 CurTIS LiNDLEY, Mines § 335 (3d ed. 1914).

${ }^{24}$ Another early test used in defining "mineral lands" was the comparative value rule, which allowed a mineral patent only when the claim was more valuable for mineral than for agricultural or other purposes. See, e.g., Ah Yew v. Choate, 24 Cal. 562, 567 (1864). The Interior Secretary repudiated the comparative value test in Cataract Gold Mining Co., 43 Pub. Lands Dec. 248, 254 (1914), although the test has occasionally reappeared in later decisions relating principally to national forests. See, e.g., United States v. Lillibridge, 4 F. Supp. 204, 206 (S.D. Cal. 1932). For a general discussion of the comparative value test and other standards of discovery, see Reeves, The Origin and Development of the Rules of Discovery, 8 LAND \& WATER L. REv. 1 (1973).

16 390 U.S. 599 (1968).

16 19 Pub. Lands Dec. 455 (1894).

17 Id. at 457.

1s See, e.g., Coleman v. United States, 363 F.2d 190, 203 (9th Cir. 1966), aff'd on rehearing, 379 F.2d 555 (1967), rev'd on other grounds, 390 U.S. 599 (1968).

19 See, e.g., Adams v. United States 318 F.2d 861, 870 (9th Cir. 1963) (under the prudent man rule, discovery "in the sense of proved ability to mine the deposit at a profit, need not be shown"). 
In 1905, in Chrisman v. Miller, ${ }^{20}$ the Supreme Court adopted a modified version of the prudent man rule as a judicial test and used it to determine which of three overlapping oil and gas locations was valid. ${ }^{21}$ The Court declared that the rule was objective, not subjective, and rejected an argument that a location was valid because the locator thought it contained a valuable deposit. Instead, the Court reasoned, the discovery rule focuses not on whether the particular locator was willing to expend more labor and means on the claim, but on whether a "man of ordinary prudence" would be justified in doing so based on what he knew. ${ }^{22}$ Otherwise, the requisite legal discovery of a valuable deposit would depend entirely on the "arbitrary will of the locator."23

The gloss in Chrisman on the objective nature of the prudent man rule reflects the purpose of all the discovery rules-to give title to lands only where a person actually discovers a valuable mineral deposit. ${ }^{24}$ But, unlike other discovery rules, the courts' adoption of the prudent man rule is also animated by the belief that the General Mining Law was passed primarily to promote mining by individual prospectors. Consequently, these courts (and favorable commentators) champion the prudent man rule because it benefits individual miners by erecting an easily satisfied discovery standard.

In Coleman v. United States, ${ }^{25}$ for example, the Ninth Circuit used the image of the lone prospector to justify its decision. There the court addressed the government's contention that the value of a locator's labor should be charged as an expense in determining profitability. The court rejected this argument and adopted the "reasonable expectation of profit" variation of the prudent man rule, reasoning that the Mining Law codified the practices of the western miner, whose history is "the essence of individualism in economic activity." Consequently, the court asserted, "academic economics has little meaning for a miner and his 'profit' is made if his receipts exceed his out-of-pocket expenditures, although he

20197 U.S. 313 (1905).

${ }^{21}$ Id. at $322-23$.

${ }^{22}$ Id.

${ }^{23}$ Id.

${ }^{24}$ See, e.g., Foster v. Seaton, 271 F.2d 836, 838 (D.C. Cir. 1959) (purpose of the requirements is "to prevent the misappropriation of lands containing these materials by persons seeking to acquire such lands for purposes other than mining").

${ }^{23} 363$ F.2d 190 (9th Cir. 1966), aff'd on rehearing, 379 F.2d 555 (1967), rev'd on other grounds, 390 U.S. 599 (1968).

${ }^{23} \mathrm{Id}$. at 203. 
may be grossly underpaid for his labor."27

In another broad reading of the Mining Law, a Nevada district court relied on the Law's historical context to determine that a claim included a property right in any roadway that a miner establishes on the public domain. ${ }^{28}$ The court declared:

To realize the force of the proposition just stated, one need but to raise their eyes, when traveling through the West, to see the innumerable roads and trails that lead off, and on, through the public domain, into the wilderness where some prospector has found a stake (or broke his heart) or a homesteader has found the valley of his dreams . . . . ${ }^{28}$

Commentators favoring the more lenient prudent man standard also generally believe that the historical purpose of the Mining Law was to help small miners. One argues that the Mining Law "is essentially a poor man's law"30 and that discovery standards stricter than the prudent man rule "eliminate the right of an individual to prospect for minerals and to work his dreams into success." 31 Another says the premise of the Mining Law is "that the public domain belonged to the people and that the mineral was to be privately acquired as a reward for discovery." ${ }^{32}$ It follows, he argues, that rules stricter than the prudent man rule are created by a "despotism" that "deride[s] the prudence of the miner and prospector."3s Even commentators who do not support the prudent man rule believe that the Mining Law was part of "a national policy of settlement and development [in which] the tradition of the prospector with a burro roaming the public lands at will in his search for minerals is practically as old as the public domain itself."34

27 Id. at 203.

${ }^{28}$ United States v. 9,947.71 Acres of Land, 220 F. Supp. 328, 331 (D. Nev. 1963).

${ }^{29}$ Id.; cf. Smelting Co. v. Kemp, 104 U.S. 636, 649-50 (1882) (looking to the practices of early miners to shed light on how many patents one person may hold).

so Mock, Marketability as a Test of Discovery Under the Federal Mining Laws, 7 Rocky MTN. Min. L. INST. 263, 269 (1962) (quoting Henry Copp, United States Mineral Lands: Laws Governing their Occupancy and Disposal preface (1881)).

s1 Mock, supra note 30, at 269.

32 Tognoni, Rule of Man vs. The American Mining Laws: The Persecution and Elimination of the Small Miner on Public Lands in the United States, 55 N.D.L. REv. 339, 339 (1979).

ss Id. at $339-41$.

s4 Hagenstein, Changing an Anachronism: Congress and the General Mining Law of 1872, 13 Nat. Resources J. 480, 483 (1973); see also Comment, The 1872 Mining Law: A Statute By-Passed by Twentieth Century Technology and Public Policy, 1981 UtaH L. REv. 575, 582 (Mining Law "absorbed the mining customs of the Gold Rush, customs adapted to 
2. The Marketability Rule. The marketability rule states that a valuable mineral deposit exists only where the minerals on the claim can be currently "extracted, removed and marketed at a profit." 35 The requirement of profitability originated in United States $v$. Iron Silver Mining Co. ${ }^{36}$ an 1888 action by the United States to cancel two placer mining claims. The United States argued that the land was valuable for its timber and lodes, but not for placer deposits. ${ }^{37}$ The defendants, however, gave evidence that the sand and gravel on the claim contained loose gold that could be extracted successfully. The Supreme Court upheld the patents, stating that "if the land contains gold or other valuable deposits in loose earth, sand or gravel which can be secured with a profit, that fact will satisfy the demand of the government as to the character of the land as placer ground." 38

While Iron Silver Mining Co. arguably held only that a showing of profitability was a sufficient condition for obtaining a patent, ${ }^{39}$ the Interior Secretary often construes the case as making profitability a necessary condition. ${ }^{40}$ Other decisions treat the marketability rule merely as a permissible alternative to the prudent man rule for both metallic and nonmetallic minerals, ${ }^{41}$ so that a miner could obtain a patent if he met either standard. Still other later cases-mostly involving common, nonmetallic minerals-mandate a showing of present marketability at a profit as an additional requirement above the requirements of the prudent man rule. ${ }^{42}$

the scale and sophistication of small scale mining"); cf. Clayberg, Some Peculiarities of Our National Mining Law, 7 YALE L.J. 53, 54-57 (1897) (describing the origins of the Mining Law); O'Callaghan, Historical Pattern of Minerals Exploration in the United States, Q. Colo. Sch. Mines, October 1962, at 31, 31-34 (same).

ss United States v. Coleman, 390 U.S. 599, 600 (1968); accord United States v. Pierce, 75 Interior Dec. 270, 278-79 (1968).

36 128 U.S. 673 (1888).

s7 Id. at 674-75.

ss Id. at 684 .

39 See Reeves, supra note 14 , at 22.

10 See, e.g., Royal K. Placer, 13 Pub. Lands Dec. 86, 89-90 (1891) (claim must be land that "will pay to mine by the usual modes"); Cutting v. Reininghaus, 7 Pub. Lands Dec. 265, 267 (1888) (same).

11 See, e.g., United States v. Dawson, 58 Interior Dec. 670, 679 (1944); 1 C. LiNDLEY, supra note 13, § 98; see also Reeves, supra note 14, at 46.

${ }^{42}$ Foster v. Seaton, 271 F.2d 836, 838 (D.C. Cir. 1959) ("the additional requirement of present marketability"); Denison v. Udall, 248 F. Supp. 942, 945 (D. Ariz. 1965) (marketability standard "applicable to common-occurrence nonmetallic mineral claims"); United States v. Pierce, 75 Interior Dec. 255, 260 (1968) (to satisfy the requirements of mining law, "there must be a present profitable market for the deposit"); United States v. Henrikson, 70 Interior Dec. 212, 217 (1963) (marketability is "an additional requirement"); United States v. 
By the 1960s the Secretary had further refined the marketability rule for nonmetals. To establish a valid discovery, a locator was required to show that his profit would not be a discouragingly small one, ${ }^{43}$ and that an actual market currently existed for the mineral. ${ }^{44}$ The locator also needed to demonstrate that the minerals for the claim were marketable independent from the operation of any other claim. ${ }^{45}$ Taken together, these requirements operated as a de facto government policy that severely restricted the disposal of federal land to mineral locators. ${ }^{46}$

3. United States v. Coleman. The marketability rule continued to apply principally to nonmetals and the prudent man rule to metals until the Supreme Court attempted to merge the two rules in 1968 in United States v. Coleman. ${ }^{47}$ The case arose when Coleman sought patents to 720 acres of building stone claims in a national forest near Los Angeles. ${ }^{48}$ Coleman claimed to have removed quartzite worth $\$ 15,990$, made improvements worth $\$ 17,200$, and invested labor worth $\$ 157,500 .{ }^{49}$ Applying the marketability rule, the Interior Secretary determined that Coleman had not discovered a valuable mineral deposit, denied the patent applications, and brought suit in district court to have Coleman ejected from the claims. Coleman counterclaimed to get review of the patent denial, but the district court granted summary judgment in favor of

Shannon, 70 Interior Dec. 136, 139 (1963) ("Because the mineral deposits . . . are nonmetalliferous minerals often of widespread occurrence, it is necessary ... to show present marketability.").

4s See, e.g., United States v. Barrows, 76 Interior Dec. 299, 310-11 (1969); United States v. Melluzzo, 76 Interior Dec. 181, 190-91 (1969); California v. Rodeffer, 75 Interior Dec. 176 (1968).

4 See, e.g., United States v. Black, 64 Interior Dec. 93, 95-96 (1957).

4s See, e.g., United States v. Chas. Pfizer \& Co., 76 Interior Dec. 331, 348 (1969); United States v. Melluzzo, 76 Interior Dec. 181, 189 (1969).

to See Reeves, supra note 14, at 4 (the Department enforces a "policy designed to prevent passage of title from the United States to the mineral claimant").

47390 U.S. 599 (1968).

4 Coleman v. United States, 363 F.2d 190, 193 (9th Cir. 1966), aff'd on rehearing, 379 F.2d 555 (1967), rev'd, 390 U.S. 599 (1968). Coleman sought the patents under 30 U.S.C. $\S 161$, which authorizes persons to "enter lands that are chiefly valuable for building stone under the provisions of the law in relation to placer mining claims." The rule of discovery for claims under this statute is the same as for placer claims under the Mining Law. 363 F.2d at 199. Besides arguing that Coleman had not discovered a valuable mineral, the government also contended that the stone was a common variety within the meaning of 30 U.S.C. § 611. This statute withdraws common varieties entirely from discovery, location, and patenting under the Mining Law. 363 F.2d at 197. The Supreme Court ultimately agreed with the government on this point. See infra note 57.

10 363 F.2d at 202; Sult, Marketability and the Mining Law: The Effect of United States v. Coleman, 7 Rocky MrN. Min. L. Rev. 77, 97 (1969). 
the government. ${ }^{\text {so }}$

The Ninth Circuit reversed. It reasoned that the Mining Law gave no justification for applying different standards of discovery to metals and nonmetals. It then held that the proper test of discovery for both was the prudent man rule. It also held that the cost of Coleman's labor need not be considered in determining whether Coleman had a reasonable expectation of profit since the Law was written with the small prospector in mind. ${ }^{51}$

The Supreme Court reversed the Ninth Circuit and upheld the Interior Secretary's use of the marketability test. ${ }^{52}$ It attempted to destroy any distinction between the two standards by viewing the marketability rule as merely a "logical complement" to the prudent man rule. ${ }^{53}$ The Court explained that "minerals which no prudent man will extract because there is no demand for them at a price higher than the cost of extraction and transportation are hardly economically valuable. Thus, profitability is an important consideration in applying the prudent-man test."54 The Court also noted that a locator's failure to meet the marketability test suggests that the land is sought for purposes other than mining. The Court concluded that metals and nonmetals were not subject to distinct tests because "the prudent-man test and the marketability test are not distinct standards, but are complementary in that the latter is a refinement of the former." bility test was often used for nonmetals for "the perfectly natural reason that precious metals which are in small supply and for which there is a great demand, sell at a price so high as to leave little room for doubt that they can be extracted and marketed at a profit."'s8 The Court's discussion of the marketability rule, however, was mere dicta. ${ }^{57}$

${ }^{30} 363$ F.2d at 193.

61 Id. at 202-03; see also supra notes 25-27 and accompanying text.

32390 U.S. at 601-02.

ss Id. at 602-03.

st Id.

ss Id. at 603. But see infra notes 70-73 and accompanying text.

so 390 U.S. at 603 . The Supreme Court seemed to assume that all precious metals are found in high concentrations. That is not true. The vast number of abandoned mines where operations were simply aborted demonstrates clearly that all precious mineral deposits are not profitable. See Braustein, Natural Environments and Natural Resources: An Economic Analysis and New Interpretation of the General Mining Law, 32 UCLA L. REv. 1133, 1172 (1985). Wild swings in the prices of precious metals can radically alter their marketability. See id. at 1172 n.229; see also Reeves, The Law of Discovery Since Coleman, 21 Rocky MTN. Min. L. INST. 415, 417 (1975) (Coleman "is . . . obviously contrary to the economic realities of the mining industry").

${ }^{57}$ In its opinion, the Court determined that the particular stone Coleman sought to 
4. Post-Coleman Cases. The cases decided after Coleman reveal problems with Coleman's attempted merger of the prudent man and marketability rules. ${ }^{58}$ The Ninth Circuit, for example, now requires "that there be, at the time of discovery, a market for the discovered material that is sufficiently profitable to attract the efforts of a person of ordinary prudence." been characterized as a flexible interpretation of the prudent man rule, and has been used to reach results inconsistent with a stricter marketability test. ${ }^{60}$ The Tenth Circuit, in contrast, applies the marketability rule, but only to actions between the government and a locator; in private actions, it concentrates on priority of location. ${ }^{61}$ The Supreme Court itself has carved out an exception to the general rule for oil shale claims by holding that such a claim's future value may be considered in assessing discovery. ${ }^{62}$ On the other hand, the Court has reiterated that a strict marketability test applies to claims for common nonmetals, despite the fact that Coleman had found that separate tests for metals and nonmetals are inappropriate. ${ }^{63}$

The Interior Secretary tries to follow Coleman by arguing that " $[t]$ here is no distinct dichotomy between present value and future

locate was a common variety within the Common Varieties Act of $1955, \S 3,69$ Stat. 368 (codified as amended at 30 U.S.C. $\$ 611$ (1982)) ("no deposit of common varieties of . . . stone . . . shall be deemed a valuable mineral deposit within the meaning of the mining laws"), see Coleman, 390 U.S. at 604. That holding is dispositive of the case, since common varieties cannot be considered valuable deposits under any discovery standard and can never be located or patented under the Mining Law. Having decided that the Mining Law did not apply to the quartzite, the court need not have discussed the proper standard of discovery under the Law. See Rodgers v. Watt, 726 F.2d 1376, 1379 n.6 (9th Cir. 1984) ("The main issue in [Coleman] ... was whether the abundance of similar material indicated that the stone was a 'common variety' and therefore excluded from the operation of the mining laws under the specific language of 30 U.S.C. $\$ 611 . ")$.

ss For a thorough discussion of the developments since Coleman, see Reeves, supra note 56, and Haggard \& Curry, Recent Developments in the Law of Discovery, 30 RockY MTN. MiN. L. INST. \$ 8.01-.03 (1984) (discussing developments since Reeves' article).

so Barrows v. Hickel, 447 F.2d 80, 83 (9th Cir. 1971); see also Rodgers v. Watt, 726 F.2d 1376, 1379 (9th Cir. 1984) (quoting Barrows).

${ }^{\circ}$ See Charlestone Stone Prods. Co. v. Andrus, 553 F.2d 1209, 1215 (9th Cir. 1977) (upholding the validity of placer claims where the enterprise was "apparently marginal," although the Interior Secretary had concluded that the miner was "a foolhardy operator"), rev'd on other grounds, 436 U.S. 604 (1978).

¿1 Hallenbeck v. Kleppe, 590 F.2d 852, 858 n.9 (10th Cir. 1979); see also Haggard \& Curry, supra note $58, \S 8.02[1][\mathrm{b}]$.

62 Andrus v. Shell Oil Co., 446 U.S. 657, 672-73 \& n.11 (1980); see also Haggard \& Curry, supra note 58, § 8.02[1][f] (discussing the "oil shale exception").

ss See Watt v. Western Nuclear, Inc., 462 U.S. 36, 57 n.18 (1983); see also McCall v. Andrus, 628 F.2d 1185, 1189 (9th Cir. 1980) (applying pure marketability test), cert. denied, 450 U.S. 996 (1981); Ideal Basic Industries v. Morton, 542 F.2d 1364, 1370 (9th Cir. 1976) (same). 
value or between present marketability and future profitability."64 The Bureau of Land Appeals, an adjudicatory branch of the Department of Interior, interprets the marketability test to require that "the mineral deposit found on the claim must be reasonably perceived to be capable of extraction, removal and marketing at a profit."6s Some Bureau decisions claim to follow "the prudent man-marketability rule" ${ }^{\text {"66 }}$ or the "prudent man test of Castle $v$. Womble requiring present marketability." deny patents, even though a claim meets the marketability test, because the discovery is so large that it will take the market a long time to absorb the production. ${ }^{68}$

\section{B. A Brief Critique}

One thing is clear about the current law of discovery: it is mired in confusion. More than a century of changing tests and definitions has created a system that is "unduly complex, burdensome and unpredictable." clarify the law in Coleman, yet its efforts have only exacerbated the problem.

Coleman tried to harmonize two incompatible rules without plainly stating the correct discovery standard.70 Coleman denied that there is any conflict between the marketability rule and the prudent man rule, claiming that "profitability" is an "important

ot E.g., United States v. Denison, 76 Interior Dec. 233, 236 (1969).

${ }^{6 s}$ E.g., United States v. Guzman, 81 Interior Dec. 685, 690 (1974).

${ }^{86}$ E.g., United States v. Taylor, 82 Interior Dec. 68, 70 (1975).

e7 E.g., United States v. Winegar, 81 Interior Dec. 370, 395 (1974) (citation omitted). This test has been described as requiring the claimant to show "as a present fact . . . that there is a reasonable likelihood of success that a paying mine can be developed." In re Pacific Coast Molybdenum, 90 Interior Dec. 352, 360 (1983). It has also manifested itself in a distinction between exploration activities, which will not satisfy the discovery standard, and development activities, which will. See, e.g., Converse v. Udall, 399 F.2d 616, 620-21 (9th Cir. 1968) (approving Department's distinction between exploratory and developmental activities), cert. denied, 393 U.S. 1025 (1969).

${ }^{8 B}$ See Baker v. United States, 613 F.2d 224, 229-30 (9th Cir.) (reversing the Bureau's "excess reserves" test), cert. denied, 449 U.S. 932 (1980); see also Haggard \& Curry, supra note 58, § 8.02[1][e] (discussing the "excess reserves" test and documenting its use after Baker).

${ }^{80}$ Haggard \& Curry, supra note 58, 88.01 (noting, however, that there is "cause for hope . . . in the form of some relaxation of the rules in decisional law and a proposal for regulatory revision of the rules").

${ }^{70}$ See Reeves, supra note 56, at 416 (In Coleman "the Supreme Court produced an opinion whose internal inconsistencies reflect the fact that the marketability rule is inherently inconsistent with the prudent man rule. Anyone who attempts to analyze Coleman in any depth soon realizes that either the Supreme Court did not understand the marketability rule or it did not understand the issue involved in the appeal."). 
consideration" in the prudent man rule. ${ }^{71}$ However true this may be, it does not reconcile the tests.

The prudent man rule examines whether one may reasonably anticipate developing a profitable mine; that is, it looks at what one may expect in the future based on what one knows now. The marketability rule examines whether the mine would be profitable currently; it looks at what one may earn now based on what one knows now. Because Coleman did not appreciate that the tests look at different evidence with respect to different timeframes, it failed to recognize the illogic of calling one rule the "logical complement" of the other. ${ }^{72}$

The consequence of this illogic is that the Department of the Interior must reconcile "the conceptual contradiction between 'present marketability at a profit' and 'reasonable prospect of success' " without the Court's help. ${ }^{78}$ Rather than loosening this "Gordian knot [the Department] has further entangled it." "The difficulty of judicial review without any fixed standard is so great that it has caused one commentator to conclude, unhappily, that there is no law of discovery, but merely departmental policy.$^{75}$ It has also left the lower courts to choose indiscriminately among the conflicting precedents. ${ }^{76}$

\section{The Preferability of the Marketability RUle}

The law of discovery-like, many argue, the Mining Law itself ${ }^{77}$-needs reform. The uncertainty surrounding this issue may deter miners from investing in and patenting mining claims, yet it does not restrain them from monopolizing areas in order to de-

71 Coleman, 390 U.S. at 602.

72 Id.

7s Haggard \& Curry, supra note $58, \S 8.01$.

74 Id.

${ }^{75}$ See Reeves, supra note 56, at 415 n.1; Tognoni, supra note 32, at 340, 352-54; see also Strauss, Mining Claims on Public Lands: A Study of Interior Department Procedures, 1974 UTAн L. REv. 185, 256; Strauss, Rules, Adjudications and Other Sources of Law in an Executive Department: The Interior Department's Administration of the Mining Law, 74 Colum. L. Rev. 1231 (1974). For a description of this policy, see supra notes 62-68 and accompanying text.

76 See supra notes 55-61 and accompanying text.

77 See Public Land Law Revisw Comm'n, supra note 4, at 124; Forman, Dwyer \& Cox, Judicial Uncertainties in Applying the Mining Doctrine of "Pedis Possessio," 3 Nat. REsources LAw. 467, 473-74 (1970); Hagenstein, Changing an Anachronism: Congress and The General Mining Law of 1872, 13 NAT. Resources J. 480, 488-93 (1973); Ladendorff, Enlarging Prediscovery Rights of Mineral Locators, 6 Rocky MTN. MIN. L. INST. 1, 25-33 (1961); Martz, Pick and Shovel Mining Laws in an Atomic Age: A Case for Reform, 27 Rocky MTN. L. REv. 375, 380-92 (1975). 
velop mineral deposits of minimal present value, even when those areas might be used more beneficially for other purposes.

The more lenient prudent man rule represents a contorted reading of the General Mining Law. The rule retains some force today largely because of the powerful historical vision of its adoption. The received wisdom is that the law was promulgated to further the interests of itinerant miners. Yet this view misunderstands the background of the Law; it was enacted to aid the burgeoning mining corporations of the West, not individual prospectors.

This section defends the marketability rule. This stricter rule is first shown to be more harmonious with the wording and structure of the statute. Then, the historical prop for the prudent man rule is examined in some detail, and shown to have little substance. At that point, little room for controversy remains. Yet the restrictions which the stricter rule imposes upon the disposal of federal lands are also shown to be more consistent with modern federal policies of environmental protection and multiple land use. Although only the legislature can reform much of current mining law, ${ }^{78}$ courts should adopt the marketability rule. This step will eliminate the confusion currently surrounding the law of discovery and will comport with the purposes of the General Mining Law itself.

\section{A. Statutory Language}

The language of the General Mining Law, while perhaps not entirely free of ambiguity, supports the use of a strict discovery test. The statute allows patents for "any land claimed and located for valuable deposits." Valuable deposits could mean three different things. It could mean marketable deposits, that is, deposits capable of being sold for some price. ${ }^{80}$ This definition would accord with a view that any mineral deposit has some inherent value, since the minerals it contains would be of some use to society. ${ }^{81}$ And it fits well with the prudent man test, which requires that the minerals can be sold, but does not require that they be sold at a

${ }^{78}$ See, e.g., Comment, The General Mining Law and the Doctrine of Pedis Possessio: The Case for Congressional Action, 49 U. CHr. L. REv. 1026, 1045-46 (1982).

79 30 U.S.C. $\$ 29$ (1982).

so See Webster's New International Dictionary 2814 (2d ed. 1935) (giving one definition of valuable as "[h]aving monetary value; being, or capable of being, sold for (such) a price").

${ }^{81}$ Another common definition of valuable is useful or serviceable. Id. 
profit. The serious drawback of this interpretation, however, is ,that it gives no meaning to the word "valuable." If any deposit were inherently valuable, and since any deposit will yield minerals that can be sold for some price, however paltry, this reading would make the term "valuable" entirely redundant.

The second possible interpretation would equate the phrase "valuable mineral deposit" with any deposit of "valuable minerals." Yet the structure of the statute does not permit this reading either. Most important, a valuable deposit is not the same as a valuable mineral. Gold is a valuable mineral, but not every deposit of it is valuable. The statute, moreover, consistently refers to "valuable deposits,"82 but never uses the phrase "valuable minerals." Finally, when the statute does refer to minerals that are inherently valuable, the term "precious metals" is used. ${ }^{84}$

The third and only plausible interpretation takes "valuable deposits" to mean deposits of significant monetary value--that is, those worth a good price. ${ }^{85}$ This definition clearly distinguishes a "valuable" mineral deposit from all other mineral deposits, which are not offered protection under the statute. ${ }^{88}$ Such a reading is compatible with a marketability test, since the determination of a "good price" would require one to take into account the costs of mineral extraction as well as some return on investment. A close reading of the language of the General Mining Law, therefore, indicates a presumption in favor of the stricter marketability rule of discovery.

\section{B. Congressional Intent and Corporate Mining}

The historical background of the General Mining Law is widely misunderstood. Supporters of the prudent man rule tend to view it as a homestead law for small placer miners. But a careful examination of the background to the three principal federal

s2 See 30 U.S.C. § 22 (1982) ("valuable mineral deposits"); id. § 23 ("other valuable deposits"); id. § 37 ("valuable mineral and other deposits"); cf. id. § 21 (lands "valuable for minerals").

ss See United States v. Feezor, 90 Interior Dec. 262 (1983). Coleman, for example, confused a valuable deposit with a valuable mineral. See Reeves, supra note 14, at 13.

s4 See 30 U.S.C. § 49a (1982).

so See Webster's New International Dictionary 2814 (2d ed. 1935) (giving one definition of valuable as "[h]aving relatively great monetary value; commanding or worth a good price").

so Cf. Cole v. Ralph, 252 U.S. 286, 307 (1920) ("Certainly it was not intended that a right to a patent could be founded upon nothing more than holding and prospecting, for that would subject non-mineral land to acquisition as a mining claim."). 
laws-the 1866 Lode Mining Act, the 1870 Placer Mining Act, and the General Mining Law-reveals that they were passed to benefit mining corporations, not individual prospectors, and offer no support for straining the statutory language to support a more permissive discovery rule.

While lone prospectors figure prominently in the early development of mining, their significance and influence had diminished by the time Congress promulgated the Mining Law. In the decade before the Law's passage, mining corporations had rapidly replaced individual miners as the primary developers of the nation's mineral resources. The new mining corporations obtained passage of favorable, uniform state mining statutes to supplant the often hostile rules of the local miners. The corporations later obtained passage of these three federal laws, which sanctioned the state statutes and provided what the states could not: secure title to mining claims on federal land. ${ }^{87}$

1. The Advent of Large-Scale Mining. The heyday of the individual prospector began when James Wilson Marshall discovered gold in the streambed at Sutter's Mill in 1848, setting off the California Gold Rush. ${ }^{88}$ Thousands of prospectors armed with picks, shovels, and pans scoured California, boosting the nation's gold production to $\$ 10$ million in $1848 .^{89}$ By 1853 the nation's gold production had reached $\$ 65$ million, ${ }^{90}$ most of it coming from Califor-

87 The language of the Mining Law itself suggests that Congress was not concerned primarily with individual miners, as advocates of the prudent man rule often suggest, but rather with corporate and associational mining. To illustrate, the Law indicates that "[a]ny person, association, or corporation" meeting certain citizenship requirements may patent a claim. 30 U.S.C. $\S 29$ (1982). Congress also provided for assessments against co-owners for the required improvements in a location, $i d$. $\$ 28$, which is a meaningless provision for lone miners, but quite useful for associations and corporations.

At first glance, it is not clear why advocates of the prudent man rule should tend to read the Law as intended to protect the interests of individual miners. Presumably one could argue that the more lenient rule of discovery would also favor corporations, which would gain more ready access to federal lands. But the explanation appears to lie in the benefits to the mining corporations of limiting competition for the lands. Under the more lenient rule, the corporations would be more likely to lose some profitable land to individual miners. Under the stricter rule, they would be less likely to lose any profitable land, and although they might not have access to as much land themselves, the land they would miss out on in this situation would be unprofitable land. One would expect, moreover, that the large corporations, reaping the benefits of scale economies, would be able to meet a marketability standard more easily than would individuals and smaller associations, which gives them an advantage under the stricter rule.

See O'Callaghan, supra note 34, at 32 . For a more detailed analysis of the economic and political history of the Mining Law than is given here, see C. MAYER \& G. RILEY, Public Domain, Private Dominion ch. 3 (1985).

89 Public Land Comm'n, The Public Domain 320 (1884).

${ }^{20}$ Id. 
nia. ${ }^{21}$ The early production came from individuals "panning" for gold. Soon, however, many placer deposits were exhausted;"2 U.S. gold production dropped from a high of $\$ 65$ million in 1853 to $\$ 39.2$ million in $1862 .{ }^{93}$

The discovery of the Comstock Lode in Nevada in 1859 initiated a pattern of lode mining that "ended the poor man's day in mining and ushered in the era of the financier and the engineer." While placer deposits could be exploited with simple equipment, lode deposits required extensive-and expensive-tunnels, stamp mills, and refining processes. ${ }^{95}$ The Comstock lode mines set the pattern for technology, cooperative activity, and capital markets that shaped the mining industry and the national mining legislation. ${ }^{.6}$

The initial developments on the Comstock were "coyote holes"-small surface excavations using placer mining techniques. By the time Congress passed the Lode Mining Act of $1866,{ }^{97}$ however, engineers had developed a mine-timbering system that permitted tunnels to depths of 3,000 feet; ${ }^{98} 46$ corporations had constructed $571 / 2$ miles of tunnels, shafts, and inclines. ${ }^{90}$ The 22 largest corporations, which accounted for 95 percent of the Comstock production, each employed an average of 63 miners and produced approximately 65 tons of ore daily. ${ }^{100}$ Precious minerals were extracted from the ores in stamp mills. By 1866, mills operating on the Comstock refined 57,112 tons of ore each month. ${ }^{101}$

91 J. Ross Browne, A Report upon the Mineral Resources of the States and Territories West of the Rocky Mountains, H.R. Exrc. Doc. No. 29, 39th Cong., 2d Sess. 50 (1867).

22 Id. at 64 .

os Public Land Comm'n, supra note 89, at 320.

o H. Barger \& S. Schurr, The Mining Industries, 1899-1939, at 101 (1944).

95 See Rodman Paul, Mining Frontiers of the Far West, 1848-1880, at 64-65 (1963). Even much of the later placer production came from associations of men using more sophisticated and costly equipment such as hydraulic cannons. H. BARGER \& S. ScHURR, supra note 94, at 98 \& n.4, 100-01; see also R. PAUr, supra, at 90-92 (describing hydraulic mining and the capital investment required).

os Eltot Lord, Comstock Mining and Minzrs, at ix-x (1883) ("Through the contention of [the Comstock's] rival locators our natural mining legislation was mainly shaped, and the colossal lottery of mining stock speculation grew out of the opportunities here first offered.").

" Lode Mining Act of July 26, 1866, ch. 262, 14 Stat. 251 (codified as amended at 30 U.S.C. $\$ \S 43,46,51,53$ (1982)). The Lode Mining Act was a forerunner of the General Mining Law of 1872. See supra note 3.

- See H. Barger \& S. Schurr, supra note 94, at 101 (describing square set timbering).

23 E. LORD, supra note 96, at 227.

${ }^{100}$ C. MAYer \& G. RILEY, supra note 88, at 61 (citing 1 AM. J. Mining, March 31, 1866, at 1).

${ }^{101}$ E. LORD, supra note 96 , at 227. 
Individuals and partnerships could not raise the capital needed to engage in such sophisticated mining operations; ${ }^{\mathbf{1 0 2}}$ so, beginning in April of 1860, mining corporations formed to pool resources, including claims, and to attract investments and loans from eastern and foreign financiers. ${ }^{103}$ Soon, stock companies owned nearly every important claim on the Comstock Lode. ${ }^{104}$ Stocks in many of the corporations were traded on the San Francisco Stock Exchange after its formation in $1862,{ }^{108}$ and journals both in the United States and abroad noted the progress of the mines. ${ }^{108}$ By 1875 the shares of thirty Comstock corporations listed on the Exchange were valued at $\$ 262,669,940 .{ }^{107}$ Nearly two-thirds of that value was for the shares of the Ophir, California, and Consolidated Virginia mining companies alone. ${ }^{108}$

The corporate mining pattern begun on the Comstock Lode was replicated at major mineral strikes throughout the West. In 1866 more than 500 corporations mined copper, gold, lead, and silver on public lands in Arizona, Colorado, Idaho, and Nevada. ${ }^{109}$ Many of the corporations established offices in Boston, Philadelphia, or New York to attract investment and promote corporate interests. ${ }^{110}$ Approximately two-thirds of Nevada's mineral production came from corporation-owned lodes, ${ }^{111}$ and corporate lode mining was also extensive throughout the West. ${ }^{112}$

102 See H. Barger \& S. Schurr, supra note 94, at 101; Clark Spence, The Sinews of American Capitalism 169-70 (1964).

${ }^{103}$ E. LoRD, supra note 96 , at 97 . The Ophir Mining Company was the first to organize on April 28,1860 , with a nominal capital of $\$ 5,040,000$. Id.

104 Id. Later many mining companies fell under the common control of the organizers of an aggressive lender, the Bank of California. For a brief but interesting history of how the Bank of California obtained almost complete control of the Comstock, see Grant Smith, The History of the Comstock Lode, 1850-1920, 37 U. NEv. BuLL., July 1, 1943, at 1, 49-51.

${ }^{103}$ E. LORD, supra note 96, at 131. For a general history of the Exchange, including the trading of shares in the Comstock corporations, see JosEPH KING, History OF THE SAN FraNcisco Stock and Exchange Board (1910).

${ }^{108}$ The Emma Silver Mining Company, Ltd., perhaps the most famous-or infamous-British investment in American mining, is a case study of the problems connected with the international promotion, organization, and operation of 19th century joint-stock companies. See Clark Spence, British Investments and the American Mining Frontier, $1860-1901 \mathrm{ch} .8$ (1958). In ten years, the company lost over 125,000 pounds sterling. Id. at 181.

107 E. LoRD, supra note 96, at 409.

${ }^{108} \mathrm{Id}$.

109 C. MAyer \& G. RILEY, supra note 88, at 64 (citing 2 AM. J. Mining, Dec. 29, 1866).

110 C. MAyer \& G. Riley, supra note 88, at 64 (citing 2 AM. J. Mining, Sept. 1, 1866).

11 R. PAut, supra note 95, at 96.

112 See Richard Lingenfelter, The Hardrock Miners 4 (1974). By 1870 Nevada's annual output of precious minerals equaled California's; from then until 1879 it greatly exceeded California's. R. Paul, supra note 95, at 96. In most western states the rise of lode 
The West's early mining corporations were but primitive precursors to modern-day mining conglomerates; they never attained the level of capitalization or managerial sophistication that the mid-nineteenth century railroads did. ${ }^{113}$ But by the time Congress passed the General Mining Law in 1872, the structure of western mining more closely resembled the corporate organization of the railroads than it did the individualism of homesteaders.

2. The Control of Local Mining Laws. As production from capital-intensive lode mines and hydraulic placer operations replaced prospecting by individuals, the new mining companies lobbied successfully for passage of favorable laws to replace the often hostile rules of the early placer miners.

The original laws of the placer miners emerged in mass meetings in mining districts without the authority of established governments. When gold was discovered in California following the Mexican-American War, the region was under U.S. military rule. The military governor, Colonel Mason, declared that the prevailing Mexican mining laws and customs were abolished as of February 12,1848 , but failed to establish any substitutes. ${ }^{114}$ Miners were forced to develop their own rules and to enforce them by vigilante committees. ${ }^{115}$

The exact content of the local codes varied, but most favored individual miners and were hostile to speculation and the accumu-

mining was neither as swift nor as complete as in Nevada. In Colorado, for example, between 1858 and 1867 , only about $40 \%$ of the state's mineral production came from lodes. Id. at 115 .

113 A precise characterization of the burgeoning western mining companies in the late nineteenth century is difficult. One widely acclaimed survey of traditional and modern business enterprises, Alfred Chandler, The Visible Hand: The Managerial Revolution in AMERICAN Busingss (1977), briefly defines a modern business enterprise as one "contain[ing] many distinct operating units and . . managed by a hierarchy of salaried executives." Id. at 1. Under Chandler's definition, some of the larger mining companies of the late $1860 \mathrm{~s}$ were no longer traditional firms; they employed middle level managers and, at times, had distinct units operating mines, mills, transportation, and investment. See, e.g., Libecap, The Evolution of Private Mineral Rights: Nevada's Comstock Lode, 144-46 (1976) (unpublished dissertation on file with The University of Chicago Law Review) (describing the hierarchy of the Bank of California's mining operations).

114 Veatch, Growth of American and Australian Mining Law, Engineering \& Mining J. 716, 716 (Apr. 2, 1910). Colonel Mason did not implement a substitute law because of "the large extent of country, the character of the people engaged and the small scattered force at my command." Id. at 716-17. Mason did propose several laws to the federal government, but none was enacted. For a brief history of the military's attempt to deal with the gold rush, see Ellison, The Mineral Land Question in California, 1848-1866, in The PuBuic LANDS 71, 71-73 (V. Carstensen ed. 1963).

115 Veatch, supra note 114, at 717. 
lation of claims. ${ }^{116}$ The laws generally recognized the discoverer's right to his claim, but usually required continual development work to retain it. ${ }^{117}$ Local rules also limited the size of claims to the area one man could work alone, and limited a person to holding only a single claim. ${ }^{118}$ The restrictions on claim size and the requirements of development were designed to prevent claims from becoming monopolized. ${ }^{119}$

In the $1850 \mathrm{~s}$, the trend shifted toward uniform rules that favored capital-intensive lode operations. ${ }^{120}$ As lode miners became politically influential, California's mining districts standardized many of their rules, while Arizona, Colorado, Montana, Nevada, and other states adopted uniform state mining codes. ${ }^{121}$ Among the first changes in the mining laws were the removal of limits on the number of claims one person could hold, changes in the allowable size of claims, and the expression of development requirements in terms of dollars per year instead of days of labor. ${ }^{122}$ These changes allowed a speculator or a mining company to hold large tracts through the hired labor of others ${ }^{123}$ - a nearly complete betrayal of the individualist placer miners' requirements for personal and continual labor in the claim.

Another change favorable to lode miners-and hence to larger mining corporations-was the widespread adoption of the "apex law" granting extralateral rights in lode claims. ${ }^{124}$ William Morris

${ }^{116}$ See Ellison, supra note 114, at 81-82.

117 Veatch, supra note 114, at 717, 719 ("One of the first-recognized and fundamental principles of . . . American . . . mining laws was that no claim could be held without development. It was considered but fair that if one man did not work the ground another should be permitted to do so."); see also Charles Shinn, Mining Camps 226-27 (1948) (describing codes in two districts, one requiring forfeiture of a claim for five days' absence from the claim, the other requiring work at least one day in three to maintain a claim).

118 See, e.g., C. SrinN, supra note 117, at 226-27 (The first article in the 1851 mining rules for Jackass and Soldier Gulches provided "[t]hat each person can hold one claim by virtue of occupation, but it must not exceed one hundred square feet." A similar provision existed in the 1852 code for the Springfield mining district.); see also Ellison, supra note 114 , at 81 (claim "size varied . . . from 10 to 150 feet square"); Veatch, supra note 114, at 719.

119 See Ellison, supra note 114, at 81.

120 R. PAUL, supra note 95 , at 171.

121 Id.; see, e.g., An Act Concerning the Location and Possession of Mining Claims, 1866 Nev. Stat. 141-52 (providing uniform regulations for possessing, holding, and abandoning claims; election of officers; recordation; claim size; and extralateral rights); see also Gregory Yale, Legal Titles to Mining Clams and Water Rights 84-85 (1867).

${ }^{122}$ Veatch, supra note 114, at 719.

${ }^{123}$ Id.

124 See Ruth Hermann, Gold and Silver Colossus: William Morris Stewart and his Southern Bride 43-44 (1975); Roy RobBins, Our Landed Heritage 221 (1976). 
Stewart, later the sponsor of the federal Mining Law, developed this innovative law in 1852. ${ }^{125}$ When codified in Nevada, the apex law gave title on the line of the claim to all "dips, spurs, angles, variations, veins, cross ledges, strings and feeders."126 The law allowed a miner to follow the located vein and intersecting veins wherever they led-even under the surface claim of another person. States justified this extraordinary deviation from the common law rule of ownership ad coelum on the basis of the "necessities" of lode mining. ${ }^{127}$

Western states and territories further aided the increasingly powerful mining corporations by granting them unusually broad rights, including powers to levy assessments on shareholders ${ }^{128}$ and to sue stockholders who were delinquent in the payment of assessments. The states exercised broad eminent domain powers to expropriate land, lumber, and other construction materials for mining operations. ${ }^{129}$ Typically the states also either exempted mining corporations from taxation or treated them very favorably. ${ }^{130}$

States also encouraged investment and reduced the risk of wealth-consuming litigation by structuring the identification of mining claims. ${ }^{131}$ The new state mining codes reduced the potential for confusion and litigation by enacting uniform procedures for locating, recording, and preserving claims. ${ }^{132}$ Legislatures also en-

125 R. HermanN, supra note 124 , at 43.

${ }^{126}$ An Act Concerning the Location and Possession of Mining Claims, 1866 Nev. Stat. 147.

${ }^{127}$ See, e.g., Bullion Mining Co. v. Croesus Gold \& Silver Mining Co., 2 Nev. 168, 178 (1866) (holding that the ad coelum doctrine, which grants a surface owner exclusive rights to all that lies beneath his land, "has but a limited application to the rights of miners and others using the public lands of this State. Necessity has compelled a great modification of that doctrine.... To adhere to the common law rules on this subject is simply impossible.").

${ }^{128}$ See, e.g., An Act Empowering Corporations and Associations for Mining to Sue Individual Members, 1862 Nev. Terr. Laws 72, in 1 Complled Laws of Nevada 32 (1873).

129 See, e.g., Dayton Gold \& Silver Mining Co. v. Seawell, 11 Nev. 394, 400 (1876); see also An Act to Provide for the Condemnation of Real Estate and Other Property Required for Mining Purposes, 1866 Nev. Stat. 196, in 1 Comprem Laws of Nevada $42-44$ (1873).

130 See Romanzo adams, Taxation in Nevada 19, 71 (1918); cf. Clark Spence, Terratorial Politics AND Governagnt in Montana, 1864-1889, at 205 (1975) ("Nowhere was the impact of the mineral interests more apparent than in the tax structure of the [Montana] territory.").

131 Litigation caused by changing local codes, spurious claims, and lack of title records often deterred investment. From 1860 to 1865, lawsuits over title on the Comstock Lode cost $\$ 10,000,000$. Reminiscences of Senator Writam M. Stewart of Nevada 146 (G. Brown ed. 1908). Senator Stewart earned about $\$ 200,000$ a year representing several mining companies during the fiercest litigation. Id. at 147.

132 See, e.g., RoBsins, supra note 124, at 221. 
acted statutes of limitations governing suits over mining claims, ${ }^{133}$ standardized conveyance methods, ${ }^{134}$ and provided government assistance in maintaining certain claims. ${ }^{135}$

State mining laws erected a framework of security that attracted investors and allowed large-scale corporate mining. The federal government validated these broad protections for corporations by adopting the General Mining Law, which mandated that local rather than federal laws would govern location methods and claim rights. ${ }^{136}$ This wholesale incorporation of state law can only have reflected a goal of further aiding the mining corporations.

3. The Battle to Secure Title. Congress's solicitude to corporate needs was further exhibited in debates over the General Mining Law. Fee title was the only critical contribution to stability which corporations could not obtain from the state legislatures: for this they turned to Washington.

The United States Constitution grants Congress explicit authority to dispose of lands owned by the federal government. ${ }^{137}$ The 1849 California Gold Rush presented national legislatures, for the first time, with the question of how to regulate mineral lands. No statute authorized the prospectors' mining; technically, they were trespassers. ${ }^{138}$ Despite the importance of the issue, Congress initially remained complacent. Perhaps the burning slavery question and the ensuing Civil War preoccupied the legislature. ${ }^{139}$

Not until 1865 did Congress act. ${ }^{140}$ Debate over the Mining Law immediately divided eastern and western representatives. Eastern congressmen drafted legislation to maximize revenue from

13s See, e.g., An Act Defining the Time of Commencing Civil Actions, $\S 4,1861$ NEv. Terr. Laws 26-31, in 1 Compried Laws of Nevada 243-44 (1873).

134 See, e.g., An Act Concerning Conveyances, § 74, 1861 NEv. TerR. Laws 11-21, in 1 Compiled Laws of Nevada 74-96 (1873).

195 See, e.g., An Act for the Protection of Mines and Mining Claims, 1862 Nev. Terr. Laws 33-34, in 1 Compiled Laws of Nevada 41-42 (1873).

138 Act of May 10, 1972, ch. 152, § 5, 17 Stat. 92 (codified as amended at 30 U.S.C. § 28 (1982)).

137 "The Congress shall have Power to dispose of and make all needful Rules and Regulations respecting the Territory or other Property belonging to the United States." U.S. Const. art. IV, § 3, cl. 2.

138 See Cong. GLOBE, 38th Cong., 1st Sess. 2557 (1864) (statement of Mr. McDougall); Paul Gates, History of Public Land Law Development 711-12 (1968); Ellison, supra note 114, at 71-72.

139 P. GATES, supra note 138, at 712-16.

140 Congress was motivated in part by its desire to capture some revenue from public lands to retire the massive Civil War debt. Cong. GLOBE, 38th Cong., 1st Sess. 2558-60 (1864) (statement of Mr. Davis). 
competitive land sales; ${ }^{141}$ westerners wanted the government to sanction the system of mining that had developed in the absence of federal control and to protect vested property rights. ${ }^{142}$ Both blocs made some vague claims to champion the small miner.

Nevada Senator William Morris Stewart ${ }^{143}$ introduced a western mining bill in 1866. ${ }^{144}$ The bill was almost identical to the 1872 Law. For lode mining, a miner retained his "extralateral right" to follow the lode or vein through all its angles, even onto adjacent property. ${ }^{145}$ There was no restriction on the number of claims or patents an individual or association could hold. ${ }^{146}$ Miners were subject to state rules and regulations that did not conflict with federal law. ${ }^{147}$

During debate on the Senate floor, Senator Stewart argued, quite disingenuously, that his bill was intended to aid prospectors who "devote three-fourths of their aggregate labor to exploration, and consequently are, and ever will remain, poor."148 With secure title and guarantees against government interference, teams of these prospectors would increase the nation's dwindling mineral production. ${ }^{149}$ Senator Stewart also suggested that small miners would benefit most from his bill, because it sanctioned free mining

${ }^{111}$ See Cong. Globe, 38th Cong., 2d Sess. 684 (1865). On February 9, 1865, Indiana Congressman George Washington Julian introduced a measure which would have established a system of public auctions for mineral lands subdivided into small tracts. Miners in possession of claims would have had preferential rights to patent their claims by purchasing the land at minimum prices. The size, location, and mineral value of the land would determine the minimum price.

Julian viewed the mines as a source of government revenue, and his bill as an attack on private monopolies. The measure was designed to protect small miners already working their claims, while raising revenue for the depleted national treasury. See P. Gates, supra note 138, at 715-16. Strong opposition by western Senators killed the bill in committee. Cong. Globe, 39th Cong., 1st Sess. 361 (1866).

${ }^{142}$ Id. at 2556-59.

14 Before arriving in Washington as Nevada's first Senator, William Stewart-educated at Yale Law School-was attorney and director for many of the large companies mining the Comstock. Obituary for William Morris Stewart, Mining \& ScI. Press 599600 (May 1909). When Stewart was seated in the Senate in 1865, he acted to establish a Committee on Mines and Mining and to guard his constituents' interests (he had originally requested a Committee on Mines and Mining Interests). P. GATES, supra note 138, at 716.

14 Some suggest the bill was an attempt by westerners to "satisfy their constituents and prevent further legislation." George Julian, Political Recollections, 1840-1872, at 287 (1884).

145 Cong. Globe, 39th Cong., 1st Sess. 3225 (1866).

14 Id. To retain a claim, a miner had to expend $\$ 1,000$ a year in labor or improvements. Once a claim was staked, it could be mined for free. A miner could patent the claim by paying a fee of five dollars an acre. Id.

167 Id.

148 Id. at 3226.

${ }^{149}$ Id. 
of claims and permitted miners to patent claims for five dollars an acre. The small prospector, according to Senator Stewart, would suffer under the competitive bidding scheme proposed by easterners where "capital [was] to compete with poverty, fraud and intrigue with truth and honesty."1so

When other congressmen reviewed the detailed provisions of the 1866 Act, however, it became apparent that the bill's framers intended it to assist mining corporations rather than prospectors. Senator Stewart's provision, for example, that a miner who did not patent a claim must expend $\$ 1000$ on improvements annually to retain the claim could not possibly benefit the lone prospector. ${ }^{161}$ And Oregon Senator John H. Williams questioned the premise that small prospectors desired security of title. Under the current system, Williams observed, "a man must remain in possession of his mine, he must work it . . . otherwise he forfeits his right to the claim." "152 Because the grant of title relieved the locator of the need to continually develop his claim, Williams cautioned that Stewart's legislation would encourage speculation and turn mining into "a monopoly in the hands of corporations or of capitalists."163

The record demonstrates that it was state legislatures and

${ }^{180}$ Id. But cf. id. at 4050 (statement of Mr. Julian suggesting that Stewart's bill leaves prospectors "to wrestle with their destiny as best they may"). Stewart and Julian also differed on the role of the federal government in overseeing the mines and protecting the small prospector. Stewart's bill would incorporate the local or state mining codes; disputes would be handled in courts of local jurisdiction. Julian's proposal envisioned greater participation by the national government in ensuring order and fair competition. Id. at 4049-50 (statement of Mr. Julian condemning local codes).

${ }^{151}$ Id. at 4051 (statement of Mr. Julian) ("It might do for my distinguished friend, the Senator from Nevada, to exact a condition of that kind; it might put money in his pocket, for aught I know, [b]ut it cannot serve the interests of the rank and file."). The $\$ 1,000$ assessment requirement for retaining a claim to a lode would also protect the large operators that had come to dominate that form of mining. During preliminary development of a mine, the assessment provision would guard the companies from competitors without the expense of acquiring a patent.

Stewart's bill further provided that state legislatures could protect western corporations that were engaged in extensive drainage and tunnelling operations. A section that was added upon Stewart's motion provided that "as a further condition of sale, in the absence of necessary legislation by Congress, the local Legislature of any State or Territory may provide rules for working mines, involving easements, drainage, and other necessary means to their complete development; and those conditions shall be fully expressed in the patent." Id. at 3453.

152 Id. at 3235 .

${ }^{16 s}$ Id. Williams also denied popular support for the legislation. Id. at 3231 ("[S]o far as I am advised, the men who are engaged in mining, the practical miners of the country, are almost, if not quite, unanimously opposed to any proposition of this kind."). Before coming to the Senate, Stewart had sponsored state legislation that was favorable to the large mining interests. See supra notes 124-29 and accompanying text; see also infra note 165 (describing Stewart's involvement with the mining companies before he entered the Senate). 
large mining associations that were most concerned with securing title to federal mining lands. ${ }^{154}$ They argued that private ownership and recognized property rights would encourage capital investment in the mining corporations. No longer would news of proposed reforms cause fluctuations in stocks that would ruin mining companies. ${ }^{155}$ This more full reading of the legislative record strongly indicates that the principal motivation behind the Mining Laws was safeguarding the interests of western mining corporations.

4. Aftermath of the Title Battle: The General Mining Law. Further consideration of the mining laws by the General Land Office and by Congress also demonstrates that the contemporary understanding of the 1866 Act was as an aid to mining corporations. For example, the General Land Office-the precursor of the Department of the Interior-interpreted the Act's legislative history as manifesting a clear intent to assist the mining corporations. In response to an 1868 query from Senator Stewart, Commissioner Wilson clarified the status of corporations under the 1866 Act. He indicated that "it would be unreasonable to suppose that [corporations] were intended to be excluded from the benefits of the [1866] law." Wise Wilson's reasoning was influenced by the Mining Law's supporters:

To exclude corporations would be to deny the privileges of the act to all the most valuable and most extensive mining claims, and would entirely disappoint the expectations of the friends of the bill on its becoming law. It is evident therefore that these bodies must be permitted to share in the benefits of the enactment. ${ }^{157}$

In 1870 Congress passed a law permitting patenting of lands containing placer deposits according to the procedures of the 1866

164 The Congressional Globe is filled with petitions and memorials imploring Congress not to sell the land according to Congressman Julian's plan. The Nevada legislature sent a memorial asking that the issue not be considered until Senators Nye and Stewart could be seated. See, e.g., id. at $360,518,979,1390,1724$.

${ }^{155}$ See, e.g., Raymond, Statistics of Mines and Mining, H.R. ExEc. Doc. No. 207, 41st Cong., 2d Sess. 424 (1870) ("Capital was afraid to buy either the old or the new title. All was uncertainty and confusion, mines unworked, miners idle, capital standing aloof. [The 1866 Act] at once restored order, certainty, and confidence .... [P]eople knew where they stood, capital was invested with safety.").

${ }^{186}$ Letter from Josiah Wilson to Register and Receiver, Land Office, San Francisco, California (Sept. 1, 1868) (National Archives, Record Group \#49, Mineral Record, vol. 1, at 260-66).

${ }^{157}$ Id. 
Act. ${ }^{158}$ Sponsors of the legislation maintained that large areas were necessary for profitable mining by corporations. For placer mining, the size of an allowable claim was expanded to 160 acres and the cost of a claim was raised to five dollars per acre. ${ }^{159}$ One Senator argued that Congress, by this action, effectively closed off " $[t]$ he only part of the mining country that a poor man can now go."160

The General Mining Law of 1872 codified the Acts of 1866 and $1870 .{ }^{161}$ Though the Law provoked little debate, some of Senator Stewart's statements again demonstrate that it was designed to maintain a system in which small miners had been supplanted by the mining companies.

In particular, California Senator Cornelius Cole proposed a change to defend the interests of the lone prospector; patent holders would be required to mine their deposits in order to retain their patents. ${ }^{162}$ Arguing in opposition, Nevada Senator Stewart completely abandoned the disingenuous claims he had made for the individual miner in the earlier debates, ${ }^{163}$ and defended the established law as a measure concerned with attracting capital and providing for growing corporations. Security of title, he argued, was a precondition to investment. ${ }^{164}$

The history of these early mining laws suggests that the impetus for them had much to do with mining corporations and little to do with individual prospectors. The legislative history reflects both the economic reality of a rapidly developing network of western mining operations and the political reality of state statutes that evolved under the influence of the ever more powerful mining

${ }_{168}$ Placer Mining Act of July 9, 1870, ch. 235, 16 Stat. 217 (codified as amended at 30 U.S.C. $\S \S 35-36,38,47,52(1982)$ ).

${ }^{168}$ See Cong. GLoBe, 41st Cong., 2d Sess. 4403 (1870). Once again, no restrictions were placed on the number of claims one could hold.

${ }^{160}$ Id. (statement of Senator Harlan); see also id. at 5043 (Senator Harlan argues that the bill "will enable men of wealth to monopolize the mineral lands").

${ }^{161}$ Cong. GlOBE, 42d Cong., 2d Sess. 532-34 (1872). Miners could still follow the vein through all its angles and to any depth, and miners could locate an unlimited number of claims. Slight alterations were made in the design and length of mining claims, but the law reaffirmed state and district authority for recording claims and settling disputes.

${ }^{182} \mathrm{Id}$. at 2459 ("My object is to insure good faith in the working of the mines to prevent their being held by owners an indefinite length of time without working them to the exclusion of the miners of the neighborhood." Otherwise the "poor miners of my own State" would be denied access to lands owned by nonresident capitalists.).

1es See supra notes 148-50 and accompanying text.

166 Id. at 2459 (" $[R]$ equiring work to be done after the patent has been issued would destroy all the virtue of your patent. . . . They will spend millions in prospecting a patented claim where they will not spend hundreds of dollars to prospect a claim where the title is uncertain and liable to be disturbed by somebody outside."). 
corporations. ${ }^{165}$

\section{Other Modern Federal Policies}

Because the legislative history convincingly demonstrates that the 1872 Mining Law was not a homestead act, it provides no support for a strained construction of the Law to favor individual prospectors who cannot profitably produce from the land. The marketability at a profit rule, moreover, comports with federal policies that have grown in importance since the Mining Law was passed. This stricter standard would help protect the environment of the public domain, a goal of modern public land statutes, and it would also prevent the monopolization of public lands unless they provide minerals valuable to the economy.

The evolution of modern multiple use statutes since 1872 reveals a consistent congressional policy to limit the disposition of public lands into private hands. Beginning with the Forest Reserve Act of $1891,{ }^{168}$ Congress began to withdraw federal land from disposal. By 1900 less than half of the original public domain remained open to entry and settlement. ${ }^{167}$ The 1920 Mineral Lands

${ }^{183}$ The legislative history of a related bill confirms that the 1872 Mining Law was not a homestead act. Congressional debates over the Sutro Tunnel scheme demonstrate sensitivity to the needs of mining corporations. In 1861, an entrepreneur named Adolph Sutro arrived in Nevada with a plan that soon attracted the interests of the leading businessmen along the Comstock. Charles Shinn, The Story of the Mine 195-98 (1906). The proposal was to build a giant drainage tunnel which would link the vertical shafts of the mining companies. Similar projects had met with success in Europe by providing easy transport of ore and by uncovering new veins. Sutro's proposal found wide support among the mining companies who agreed to pay a fixed rate for removal of waste.

William Stewart became the first president of the Sutro Tunnel Company, formed in 1864. San Francisco Daily Evening Bull., July 16, 1866. He guided a bill through Nevada's First State Legislature granting his company a franchise, right-of-way, and other privileges such as state bonds. An Act of February 4, 1865 Granting the Right of Way and Authorizing A. Sutro and His Associates to Construct a Mining and Drainage Tunnel, 1865 Nev. STAT. 128. When Stewart entered the U.S. Senate he remained president of the Sutro Tunnel Company and helped to pass a bill granting federal rights to Sutro similar to those granted by the Nevada statute. See Act of July 25, 1866, ch. 244, 14 Stat. 242; Cong. GLoBE, 39th Cong., 1st Sess. 2957, 2980, 3505, 4062 (1865).

The Mining Law of 1872 also recognized the corporate interests in the Sutro Tunnel. It provided that "[n]othing in this act shall be construed to repeal, impair, or in any way affect the provision of the act entitled 'An act granting to A. Sutro the right of way, and other privileges to aid in the construction of a draining and exploring tunnel to the Comstock lode, in the State of Nevada,' approved July twenty-fifth, eighteen hundred and sixty-six." Act of May 10, 1872, ch. 152, 17 Stat. 91, 95.

${ }^{168} \mathrm{Ch} .561, \S 24,26$ Stat. 1095,1103 (1891) (codified as amended at 16 U.S.C. $\S \S 471$, 607-610 and scattered sections of $30,35 \& 42$ U.S.C. (1982)).

187 E. Louise Perper, The Closing or the Public Domain 8 (1951). 
Leasing Act $^{168}$ gave the Interior Secretary authority to remove oil, natural gas, and coal from the disposal mechanism of the 1872 Mining Act and lease those resources for royalties and rentals. The Taylor Grazing Act of $1934^{168}$ remedied the deterioration of western range lands by allowing the Secretary to classify millions of acres of public land according to their most suitable use.

Congress also modified the Mining Law to conform it to modern multiple use principles. In 1955 Congress curbed abuses of the Mining Law by enacting the Multiple Surface Use Act, ${ }^{170}$ which removed deposits of common varieties of sand, stone, gravel, and other minerals from the coverage of the Mining Law and made these minerals available for sale only under the Materials Act of 1947. ${ }^{171}$ The 1955 revision further provided that deposits of these common substances would be locatable and patentable only if they possessed some peculiar property which gave them a "distinct and special value."172

Congress next passed the Classification and Multiple Use Act of $1964,{ }^{173}$ declaring a policy of multiple use for the public domain. The Act authorized the Secretary to classify all lands administered by the Department of the Interior in order to provide for their disposal or retention and management under principles of multiple use. The authority given the Secretary to classify public lands included, for the first time, the power to withdraw classified land from the jurisdiction of the Mining Law. ${ }^{174}$ This action was the first implicit expression of congressional support for the Department's effort to administer the Mining Law under the concept of multiple use. It also indicated implicit approval of the Department's use of a marketability test to limit the disposal of federal

${ }^{168}$ Mineral Lands Leasing Act, ch. 85, 41 Stat. 437 (1920) (codified as amended at 30 U.S.C. $\S \S 181-287$ (1982)).

${ }^{169}$ Ch. 865 , 48 Stat. 1269 (1934) (codified as amended at 43 U.S.C. $\$ \S 315-315$ r (1982)).

${ }^{170}$ Ch. 575, 69 Stat. 367 (1955) (codified as amended at 30 U.S.C. $\$ \S 601-615$ (1982)).

${ }^{171}$ Ch. 406, 61 Stat. 681 (1947) (codified as amended at 30 U.S.C. $\$$ 601-604 (1982)). The Materials Act authorized the sale of materials such as sand, gravel, stone, and clay from federal lands. Ownership of the lands was retained by the government.

172 Note, Marketability and the Mining Law: the Effect of United States v. Coleman, 10 ArIz. L. Rev. 391,407 (1968). The Multiple Surface Use Act, however, provided for multiple surface use of unpatented claims only; it had no effect on a claim once it went to patent. Id. at 408. Since a holder of an unpatented claim could still acquire a patent by showing a discovery of a "valuable mineral deposit," the Interior Department remained unauthorized to limit the disposal of federal land by imposing a stringent discovery standard.

${ }^{173}$ Pub. L. No. 88-607, 78 Stat. 986 (codified as amended at 43 U.S.C. $§$ 1411-1418 (1982)),

${ }^{274} I d$. at $\S 4,78$ Stat. 987. 
lands for private mining use. ${ }^{175}$

This succession of laws reflected a piecemeal change of federal policy. Gradually the disposal of portions of the federal land was restricted; the presumption remained, however, that all lands were free for disposal. Yet the Federal Land Policy and Management Act of $1976^{176}$ represented an even sharper change of attitude. It unequivocally declared the public policy of the United States to be retention of public ownership of public lands. ${ }^{177}$ It further required the Secretary, in regulating the use of federal lands, to manage the property so as to permit a variety of uses, including historic preservation, logging, grazing, and agriculture. ${ }^{178}$

If the rights of miners as codified in the 1872 Law continue to be extended by the more liberal prudent man rule of discovery, they will tend to frustrate this goal of land management. ${ }^{179}$ Only a strict marketability standard can conform the 1872 Mining Law with multiple use statutes. By placing the burden of proving a valuable mineral deposit squarely on the claimant, the marketability standard ensures that land is removed from federal ownership only when there is clear justification for doing so. While any removal may undermine efforts to protect the environment and other public uses, requiring compliance with a strict marketability standard would allow mining use only in situations where one may be reasonably confident that the social gains from disposal outweigh the costs to society. ${ }^{180}$ As a practical matter, the marketability at a

${ }^{176}$ In applying the Multiple Surface Use Act, for example, the Department had determined that a "distinct and special value" would exist only if the mineral value would render the land more useful as a mining site than if it were dedicated to continued public multiple use. See Note, supra note 172 , at 407.

${ }_{176}$ Pub. L. No. 94-579, 90 Stat. 2743 (1976) (codified as amended at 43 U.S.C \$§ 17011784 (1982)).

17743 U.S.C. $\$ 1701(\mathrm{a})(1)(1982)$.

${ }^{178} I d$. $\S 1712(\mathrm{c})$. Although the FLPMA expressly protects rights guaranteed under the Mining Law, id. $\S 1732(\mathrm{~b})$, the marketability rule would not impair any rights that have already vested. If it were argued that the rule would affect existing expectations, the response would be that mere expectations are not protected under the law, especially against a discovery standard that has been in existence with considerable force since 1894. The FLPMA, moreover, allows the Interior Secretary to "take any action necessary to prevent the unnecessary or undue degradation of the lands." Id.

178 Environmental concerns are particularly slighted by the Mining Law. Modern mining may destroy vegetation, cause soil erosion, pollute streams, disrupt groundwater aquifers, and scar landscapes. See U.S. General Accounting OfFICE, supra note 10, at 24 ("The Mining law of 1872 has no provision for protecting or rehabilitating lands covered by mining claims or mineral patents.").

${ }^{180}$ See Braustein, supra note 56, at 1178-1201 (arguing that economic analysis of the social costs and benefits of mining on public lands requires use of the marketability rule of discovery). 
profit standard is the only device that allows the Department of the Interior to manage public lands properly. ${ }^{181}$

A marketability standard would protect other interests of the federal government. Current standards often provide inadequate revenue to the federal treasury ${ }^{182}$ and allow illegitimate claimants to acquire public lands fraudulently. ${ }^{183}$ Requiring strict proof of profitability would ensure that when the federal government sells land for very low prices, it does so for a good reason: to encourage production of minerals valuable to the nation's economy. ${ }^{184}$ Requiring a claimant to prove marketability would also prevent claimants from duplicitously acquiring mineral land for illegiti-

181 Public Lands Review: Hearings on H.R. 8070 Before the Subcomm. on Public Lands of the House Comm. on Interior and Insular Affairs, 88th Cong., 1st Sess., ser. no. 11, pt. 2, at 50 (1963) (statement of Acting Interior Secretary Carver).

Among the congressional objectives stated in the current version of the statute is an explicit recognition of the need for such multiple use management: "the orderly and economic development of domestic mineral resources, reserves, and reclamation of metals and minerals to help assure satisfaction of industrial, security, and environmental needs." 30 U.S.C. \& 21a.

${ }^{182}$ The subsidy doctrine of the 1872 Mining Law is an anachronism in this age when most users of the public domain must pay for that privilege. Today, a mining company can still patent a claim at the 1872 price of $\$ 2.50$ or $\$ 5.00$ per acre. 30 U.S.C. $\$ \S 29,37$ (1982). Lumber companies lost free access to federal timber land in 1896. Cattle and sheep ranchers must pay a grazing fee to enter national parks. Council on ENvironmental Quality, HarDRock Mining on Public LAND 11 (1977) ("To go on the Toiyabe National Forest to harvest piñon nuts, you must buy a permit, but the gold or silver is free.").

The United States receives royalties for hard rock minerals taken on only 56.3 million acres ( $8 \%$ of the public domain) of acquired land-land bought from private owners. Mineral Leasing Act for Acquired Lands, Pub. L. No. 80-382, 61 Stat. 913 (1947) (codified as amended at 30 U.S.C. $\S \S 351-359$ (1982)). In 1977, the Council on Environmental Quality estimated that the U.S. government would collect $\$ 120$ million annually if the small royalties charged for mining on acquired land were levied on the $\$ 3$ billion hard rock mineral production from all other federal lands. Councr. on ENvironmental Qualiry, supra, at 12. In 1982, one critic estimated that, in reality, $\$ 12$ to $\$ 15$ billion in hard rock minerals are annually taken from public lands. Conlin, The Claims Game, Wilderness, Fall 1982, at 17, 23.

18s In 1974, the General Accounting Office studied 93 randomly selected patents in four western states. Of the 93 tracts, only 7 were being mined, 66 were apparently put to no use, and 20 were devoted to non-mining purposes. Patented lands were used for resorts, junkyards, shopping centers, and even a house of prostitution. U.S. GENERAL AccounTing OfFICE, supra note 10 , at 11-12, 34-39.

Miners counter that a prudent man standard is necessary to protect the locator while prospecting a claim. Faced with the prospect of losing his claim under a marketability standard, the miner has no security and no incentive to invest and prospect. The solution to this problem is not to abandon the marketability doctrine which applies to patenting claims, but to strengthen pre-patent protections such as the doctrine of pedis possessio. See Comment, supra note 78.

${ }^{184}$ Indeed, the intent of the Mining Law was, in part, to increase production of valuable minerals in order to improve a national economy reeling from the Civil War. Cong. GLOBE, 39th Cong., 1st Sess. 3229 (1866) (statement of Senator Conness). 
mate purposes such as building homes.

Finally, a strict marketability at a profit rule would be easy to administer. Difficult questions of the prospectors' intentions, of future profitability, and of possible changes in technology are avoided under this standard. ${ }^{185}$ Perplexing issues of whether the prospector intends to defraud the government or to build a home on his claim need not be reached. Frequently, when a locator has worked his claim for years before applying for a patent, there will be abundant evidence of lack of profitability. Even for a claimant who has not been prospecting a claim, gathering evidence about present marketability is much easier than speculating about future economic conditions.

\section{CONCLUSION}

Passage of the General Mining Law of 1872 was a logical extension of statutes tailored for mining corporations at the state and federal level. Far from enshrining the laissez-faire regime of the mining camps, the Law returned control to state capitols. It granted federal title while codifying state rules drafted to benefit burgeoning corporations rather than nomadic placer miners. These driving forces behind passage of the Law go unrecognized by those who view it as a homestead law for itinerant prospectors.

Commentators who argue for a liberal discovery standard-the prudent man rule-tend to misinterpret the Act's use of the phrase "valuable mineral deposits." This comment argues that a more stringent discovery standard requiring mining claimants to demonstrate present marketability at a profit is more consistent with the language and history of the Law. Given that Congress was acting primarily for the benefit of larger mining corporations, there is no justification for construing the Law favorably for the benefit of the small prospector. A strict marketability rule would allow management of the federal lands in a manner more consistent with the goals of modern multiple use statutes, and would prevent these public lands from being plundered by spurious claimants.

Carl J. Mayer

ses See Hochmuth, Government Administration and Attitudes in Contest and Patent Proceedings, 10 Rocky MTN. MIN. L. INST. 467, 477-78 (1965) (recommending marketability standard); cf. Braustein, supra note 56, at 1184-94 (discussing the merits of an opportunity costs standard). 